\title{
Rapeseed protein as a novel ingredient of gluten-free bread
}

\author{
J. Korus ${ }^{1} \cdot$ A. Chmielewska ${ }^{2,3} \cdot$ M. Witczak ${ }^{4} \cdot$ R. Ziobro ${ }^{1} \cdot$ L. Juszczak $^{5}$
}

Received: 8 March 2021 / Revised: 22 April 2021 / Accepted: 24 April 2021 / Published online: 8 May 2021

(c) The Author(s) 2021

\begin{abstract}
The aim of the study was to analyze the influence of rapeseed protein isolate on physico-chemical properties, sensory attributes and storage of gluten-free bread prepared on the basis of corn and potato starch mixture with the addition of pectin and guar gum. Starches used in bread formulation were replaced with rapeseed protein isolate in the amounts 6-15\%. The bread was characterized in terms of physical properties, including volume, crumb structure and color, which was accompanied with sensory assessment. Texture and thermal properties were determined during 3 days of storage. It was observed that the presence of rapeseed protein, especially at higher levels, caused an increase in bread volume and density of pores and a decrease in crumb porosity, as compared to the control. Partial replacement of starch with rapeseed protein caused a significant increase of $b^{*}$ parameter, reflecting rising yellowness, which positively influenced bread acceptance. Rapeseed protein limited bread staling during storage in comparison to control sample. The results demonstrate that rapeseed protein could become a valuable component of gluten-free bread, as it provides valuable amino acids, but also beneficially influences quality characteristics.
\end{abstract}

Keywords Rapeseed protein $\cdot$ Gluten-free bread $\cdot$ Texture $\cdot$ Sensory acceptance $\cdot$ Bread staling

\section{Introduction}

Due to protein deficiency, gluten-free bread, which is often based on starches of various botanical origin [1-3] and structure forming non-starch hydrocolloids, usually reveals relatively low nutritional value. According to Melini et al. [4], commercial gluten-free bread mixes contain mostly carbohydrates, including rapidly digested starch, which significantly

L. Juszczak

rrjuszcz@cyf-kr.edu.pl

1 Department of Carbohydrate Technology, University of Agriculture in Krakow, Balicka 122 Str., 30-149 Kraków, Poland

2 NapiFeryn BioTech Sp. z o.o., Dubois 114/116 Str., 93-465 Lodz, Poland

3 Department of Starch Technology and Confectionary, Lodz University of Technology, ul. Wólczańska 171/173, 90-924 Lodz, Poland

4 Department of Engineering and Machinery for Food Industry, University of Agriculture in Krakow, Balicka 122 Str., 30-149 Kraków, Poland

5 Department of Food Analysis and Evaluation of Food Quality, University of Agriculture in Krakow, Balicka 122 Str., 30-149 Kraków, Poland increases the value of glycemic index of such products. Such bread formulations also have adverse effects on the supply of protein and thus amino acids in the diet [5-7]. Lack of protein in gluten-free carbohydrate-based bread adversely affects the sensory characteristics, especially the color and aroma $[4,8]$. Many authors indicate that the addition of proteins of various origins results in a darker color of the crumb [9-12] which is desired by consumers as associated with traditional bread. The contribution of protein to the aroma of bread during baking is also an important factor influencing the sensory characteristics and improving the acceptability of this type of product [13]. In the literature can be find numerous data on enriching gluten-free bread with protein, whether using gluten-free flours containing native proteins or using isolates or concentrates of plant or animal proteins [14-20]. These proteins, in addition to improving nutritional value, can positively affect the structure and sensory characteristics of the finished product.

Rapeseed protein can be used as a novel food ingredient, in the production of gluten-free products, including bread, on the basis of the Commission Implementing Decision of 1 July 2014 [21]. According to the definition given in the decision, rapeseed protein isolate is a protein-rich $(>90 \%)$ water extract derived from a press cake left after the extraction of 
oil from genetically unmodified varieties of Brassica napus L. and Brassica rapa L. Rapeseed protein isolate can be used in processing as a food ingredient due to its balanced amino acid composition and such functional properties as the ability to form foams and gels and to stabilize emulsions [22, 23]. Favorable amino acid profile, surpassing soy protein isolate and comparable with FAO/WHO/UNU standard is a major benefit of rapeseed protein isolate from nutritional point of view [23].

The use of proteins of various origins in gluten-free product technology, including bread, is already widely described in the literature on the subject [6], but there is no information about the possibility of using rapeseed protein isolate as a component enriching, structuring and improving the sensory characteristics of bread. The aim of the study was to assess the effect of rapeseed protein isolate on physical properties, sensory characteristics and staling of gluten-free bread during 3-day storage.

\section{Materials and methods}

\section{Materials}

Gluten-free bread was manufactured using the following components: corn starch (Bezgluten, Poland), potato starch (PPZ Trzemeszno, Poland), guar gum (Bezgluten, Poland), pectin (Bezgluten, Polska), freeze-dried yeast (S.I. Lesaffre, France), sucrose, salt, rapeseed oil (acquired from a local store), water and rapeseed protein isolate (Raptein ${ }^{\mathrm{TM} 90)}$ containing $96.33 \%$ d.b. protein according to the producer (NapiFeryn BioTech, Łódź, Poland).

\section{Methods}

\section{Dough preparation and baking of gluten-free bread}

The dough for gluten-free bread was obtained from the following ingredients and additives: corn starch and potato starch (mixed in a ratio 4:1) $600 \mathrm{~g}$, rapeseed oil $18 \mathrm{~g}$, sucrose $12 \mathrm{~g}$, salt $11.5 \mathrm{~g}$, pectin $10 \mathrm{~g}$, guar gum $10 \mathrm{~g}$ and water $570 \mathrm{~g}$. In non-control samples, part of starches were replaced in proportion to the share in the blend with rapeseed protein isolate at $6,9,12$ or $15 \%$ level calculated in relation to the total weight of both starches. The amount of water needed for individual formulations was established in preliminary studies with the use of texture analyzer TA-XT2+ equipped with back extrusion rig (A/BE-d 35) (Stable Micro Systems, England). These studies checked the amount of water needed to make a dough of the same consistency (hardness) as the control dough. It is assumed that the maximum difference in hardness compared to the control dough can be up to $5 \%$.
After weighing, all dough ingredients were mixed for 8 min (Laboratory Spiral Mixer SP 12, Diosna, Germany). The resulting dough was fermented for $15 \min \left(35^{\circ} \mathrm{C}\right.$, $80 \%$ relative humidity) and re-mixed for $1 \mathrm{~min}$. Pieces of dough $(250 \mathrm{~g})$ were weighed into greased metal tins. The final proofing lasted 20 min under the conditions as stated before. Loaves were baked for $30 \mathrm{~min}$ at $230{ }^{\circ} \mathrm{C}$ (MIWE Condo deck oven type CO 2 0608, MIWE GmbH, Germany). After being, the breads were removed from the tins, cooled at ambient temperature and used for further analyses. To evaluate changes in texture parameters during storage, some samples were packed in polyethylene bags and stored at $22 \pm 2{ }^{\circ} \mathrm{C}$.

\section{Nutritional composition of bread}

The protein content of the analyzed bread was determined by the Kjeldahl method $(N \times 5.7)$ according to the AOAC No. 950.36 methodology, using the B324 distillation unit (Büchi Labortechnik, Switzerland), fat content by the Soxhlet method in accordance with AOAC procedure No. 935.38, using Büchi B811 extractor (Büchi Labortechnik, Switzerland), total carbohydrates by AOAC Method No. 974 and dietary fiber content determined by enzymatic-gravimetric method using Megazyme test kit (Megazyme International Ireland Ltd., Ireland) according to AOAC 991.43 [24].

\section{Physical characteristics of bread}

Bread volume was determined using a laser-based non-contact volume measurement instrument Volscan 600 (Stable Micro Systems, England). The image analysis was carried out for 1-cm-thick slices taken from the inner parts of each loaf, which were scanned with a flatbed scanner S-12. The recorded images were analyzed with the ImageJ v. $1.44 \mathrm{c}$ software. Porosity (area of pores divided by total area), cell density (the number of pores per area unit) and the percentage of pores with diameter above $5 \mathrm{~mm}$ were calculated.

\section{Color and sensory acceptance of the bread}

Analysis of crumb color in CIE $L^{*} a^{*} b^{*}$ system was performed by reflection method using Color i5 (X-Rite, USA) spectrometer with the following settings: geometry $\mathrm{d} / 8$, illuminant D65, observer $10^{\circ}$, aperture $25 \mathrm{~mm}$.

Sensory acceptance of bread was performed by a sensory panel composed of 14 persons with established sensory sensitivity. The method of sensory evaluation was based on the analysis of acceptance of coded bread samples on a sevenpoint scale, where 1 means "extremely dislike" and 7 means "very like". The analysis included the following qualitative characteristics: overall appearance, structure and porosity, color, smell and taste. 


\section{Bread texture}

Texture profile analysis (TPA) of bread crumb was performed using texture analyzer TA-XT2plus (Stable Micro Systems, England) at compression rate $5 \mathrm{~mm} / \mathrm{s}$. Cylindrical bread crumb sample with height and diameter of $2 \mathrm{~cm}$ was compressed to achieve $50 \%$ deformation using a P/20 aluminum cylindrical probe, in two cycles. The values of hardness, springiness, cohesiveness and chewiness were used as indicators of crumb texture changes during storage. The calculations were done using Texture Exponent software (Stable Micro Systems, England). The analyses were carried out after 2, 24 and $48 \mathrm{~h}$ after baking.

\section{Thermal characteristics of bread}

Thermal properties of the bread crumb were determined using differential scanning calorimeter DSC 204F1 Phoenix (Netzsch, Germany). The loaves after baking were cooled for $2 \mathrm{~h}$. After that time, samples (approx. $15 \mathrm{mg}$ ) were taken for thermal analysis which was also done after 24 and $48 \mathrm{~h}$. The samples were hermetically closed in aluminum pans and heated in the calorimeter from 20 to $100^{\circ} \mathrm{C}$ at a rate $10^{\circ} \mathrm{C} /$ min. Empty pan was used as a reference. Phase transition temperatures and enthalpy were calculated using Proteus Analysis software (Netzsch, Germany). Enthalpy values were expressed in $\mathrm{J} / \mathrm{g}$ of d.b.

\section{Statistical analysis}

To assess the significance of the differences between the averages, the data were subjected to a single-factor analysis of variance and the differences between the averages were determined using Duncan's post hoc test at a significance level of 0.05 . To determine the effect of both protein addition and storage time, a two-factor ANOVA was also performed for the texture profile analysis and thermal properties. The relationships between the analyzed parameters were evaluated using the values of Pearson correlation coefficients. The calculations were performed using the Statistica 11.0 (StatSoft Inc., USA).

\section{Results and discussion}

\section{Nutritional composition of bread}

The control bread contained $1.51 \%$ protein, $2.14 \%$ fat, $45.61 \%$ carbohydrates and $1.35 \%$ dietary fiber. The introduction of rapeseed protein into the recipe contributed to a significant $(p>0.05)$ increase in protein content to $9.60 \%$ with the highest $15 \%$ replacement of starch with a protein preparation. At the same time, there was a significant $(p<0.05)$ decrease in the carbohydrate content to $38.32 \%$ with the highest $15 \%$ replacement of starch with a protein preparation. The enrichment of the dough recipe with rapeseed protein did not have a significant effect on fatty substances, the content of which ranged from 2.12 to $2.27 \%$. The presence of rapeseed protein also had little effect on the level of dietary fiber, the content of which ranged from $1.35 \%$ for the control sample to $1.68 \%$ for breads where the most starch was replaced by a protein preparation.

\section{Loaf volume}

Loaf volume (Fig. 1) is the first parameter allowing to evaluate the influence of ingredients on bread quality. Its lowest value was found for control and samples containing 6 and 9\% share of rapeseed protein isolate (RPI). Larger addition of RPI (12 and $15 \%$ share) resulted in significant $(p<0.01)$ increase in bread volume. Bread volume is controlled, among other factors, by the ability of the dough to retain fermentation gases. The presence of rapeseed protein in the dough did not have a significant impact on its water absorption and retention, so all analyzed formulations contained the same amount of water. Therefore, the concentration of protein seems to be the key factor which could influence bread volume. Rapeseed protein due to its surface activity could stabilize the fermentation gas bubbles closed in the crumb structure. A larger volume of bread has a positive effect on the acceptance of the bread, so from the consumer's point of view it is a desirable factor. Supplementation of gluten-free bread with proteins of various origin results in significant, but not uniform changes in its volume. Witczak et al. [25] observed a significant decrease of gluten-free bread in which starches were partially replaced with potato protein in quantities of $2-10 \%$. Similar decrease was also reported after the addition of cricket powder in quantities

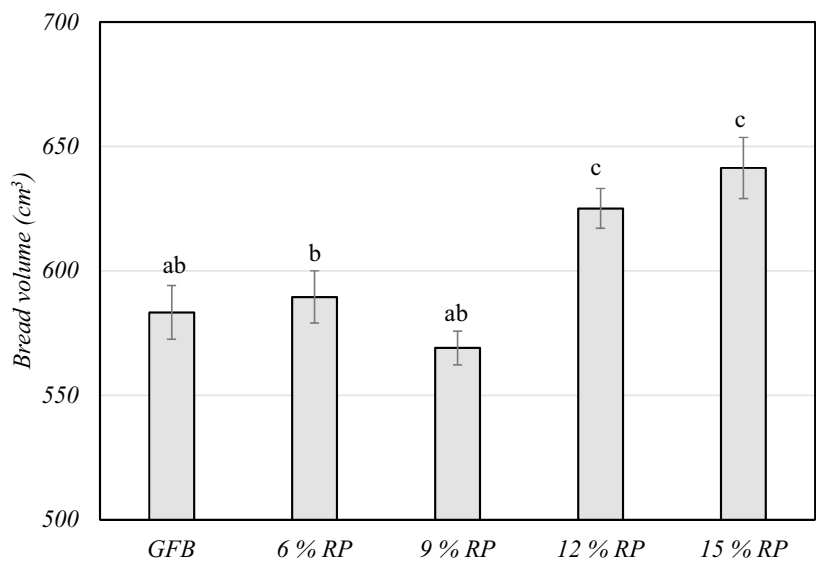

Fig. 1 Volume of control gluten-free bread (GFB) and samples enriched with rapeseed protein (RP). Mean values signed this same letters are non-significant different at 0.05 level of confidence 
10 and $20 \%$ by weight of flour/starch [9]. In the study of Coşkun et al. [12], bread volume decreased after the addition of various protein concentrates at the level of $1.5 \%$, but its extent could be diminished by larger addition of water. On the other hand, Phongthai et al. [26] observed increasing loaf volume after the enrichment of bread recipe with $2 \%$ rice protein concentrate and albumin. In addition, Han et al. [27] observed an increase in bread volume after replacing part of gluten-free flour, at a level of 5-15\%, with dried egg white. Similar tendency was found by Graça et al. [28] in the case of replacement of gluten-free flour and starch in the amount of 5-20\% with yogurt. In the study of Ziobro et al. [8] on the effects of various proteins, replacing $10 \%$ of the base starch, on characteristics of gluten-free bread, it was found that albumin and lupin proteins cause an increase in bread volume, while collagen and soy proteins result in its reduction.

\section{Physical characteristic of bread crumb}

The share of rapeseed protein in the recipe also influenced the characteristics of the crumb (Table 1). A significant $(p<0.01)$ decrease in the porosity of the crumb of bread with rapeseed protein was found in comparison to the control sample, although the level of addition of this ingredient alone was not significant. Similar decrease was also noticed by Witczak et al. [25] after enriching gluten-free bread with potato protein between 2 and $10 \%$. The addition of rapeseed protein resulted in a significant $(p<0.01)$ increase in density of pores (Table 1), compared to the crumb of control bread. The level of protein addition itself was not important here, as the highest pore density was found for the bread crumb with the lowest and highest share of protein. The presence of rapeseed protein in the formulation significantly $(p<0.01)$ reduced the percentage of large pores $>5 \mathrm{~mm}$ (Table 1) and, as before, the level of protein addition itself was not important. The results concerning the characteristics of the crumb clearly indicate that the presence of rapeseed protein in the

Table 1 Digital image analysis parameters of gluten-free bread crumb

\begin{tabular}{llll}
\hline Sample & Porosity (-) & $\begin{array}{l}\text { Cell density } \\
\left(\mathrm{cm}^{-2}\right)\end{array}$ & $\begin{array}{l}\text { Percentage of } \\
\text { pores }>5 \mathrm{~mm}\end{array}$ \\
\hline Control GFB & $0.379 \pm 0.005^{\mathrm{c}}$ & $3.71 \pm 0.31^{\mathrm{a}}$ & $0.094 \pm 0.008^{\mathrm{c}}$ \\
$6 \% \mathrm{RP}$ & $0.332 \pm 0.004^{\mathrm{a}}$ & $4.80 \pm 0.19^{\mathrm{c}}$ & $0.054 \pm 0.005^{\mathrm{a}}$ \\
$9 \% \mathrm{RP}$ & $0.349 \pm 0.008^{\mathrm{b}}$ & $4.00 \pm 0.28^{\mathrm{ab}}$ & $0.076 \pm 0.012^{\mathrm{b}}$ \\
$12 \% \mathrm{RP}$ & $0.334 \pm 0.021^{\mathrm{a}}$ & $4.36 \pm 0.47^{\mathrm{b}}$ & $0.061 \pm 0.008^{\mathrm{a}}$ \\
$15 \% \mathrm{RP}$ & $0.332 \pm 0.005^{\mathrm{a}}$ & $4.83 \pm 0.13^{\mathrm{c}}$ & $0.051 \pm 0.007^{\mathrm{a}}$ \\
One-way & $<0.01$ & $<0.01$ & $<0.01$ \\
ANOVA- $p$ & & & \\
\hline
\end{tabular}

Mean value of three replication \pm standard deviation

Mean values signed this same letters in particular columns are nonsignificant different at 0.05 level of confidence bread recipe significantly affects changes in the characteristics of its structure causing a decrease in porosity, with a significant decrease in the number of large pores $(>5 \mathrm{~mm})$ and an increase in the number of pores per unit area. This is due to the beneficial effect of the protein associated with its surface activity and ability of stabilizing the foam structure of the crumb. The improvement of crumb porosity under the influence of $2 \%$ rice proteins and albumin was found by Phongthai et al. [26]. According to Bravo-Núñez et al. [29], hydration level of protein is another important factor affecting characteristics of bread enriched with such preparations, as it affects crumb elasticity and gas retention ability. The water content of the rapeseed protein was similar to that of the base starch, so replacing part of the starch with this protein did not alter the hydration level, regardless of the level of the replacement. An increase in the porosity of the bread crumb after replacing in the recipe 10 and $20 \%$ of the base starch with the hemp protein concentrate was observed by Korus et al. [10]. In addition, da Rosa Machado and Thys [9] reported an increase in crumb porosity and pore density, after the application of 10 or $20 \%$ cricket powder which was accompanied by a decrease in the number of large pores. An increase in porosity with a simultaneous decrease in pore density was also found by Ziobro et al. [8] when $10 \%$ of the base starches were replaced with protein of various origin for gluten-free bread enrichment.

Changes in the characteristics of the crumb are also confirmed by its photographs shown in Fig. 2. The structure of the control bread was characterized by the presence of many pores of considerable size (Fig. 2a, b). The presence of protein, already in the lowest concentration, affected the image of the crumb structure, as a decrease in the number of large pores could be observed (Fig. 2c). A clear decrease in the number of large pores and an increase in the number of fine pores could be observed on the crumb images of samples with increasing content of rapeseed protein (Fig. 2d-f). The crumb of this bread was more homogenous with more evenly distributed pores of smaller sizes. Such crumb structure is more desirable and acceptable by consumers. The images of the crumb structure shown in Fig. 2 also indicate the darkening of the color caused by the presence of rapeseed protein in the recipe.

\section{The color of the bread crumb}

Partial replacement of starch with rapeseed protein isolate caused a significant $(p<0.01)$ change in crumb color (Table 2). The lowest proportion of rapeseed protein in the recipe caused a slight increase in brightness $\left(L^{*}\right)$ and $a^{*}$ parameter with a very high increase in $b^{*}$ value, which indicates an increasing proportion of yellow. Further increase in the amount of rapeseed protein in the recipe resulted in a slight decrease in crumb brightness compared to the control 
Fig. 2 Images of control glutenfree bread $(\mathbf{a}, \mathbf{b})$ and samples with rapeseed protein $6 \%(\mathbf{c})$, $9 \%(\mathbf{d}), 12 \%(\mathbf{e})$ and $15 \%(\mathbf{f})$

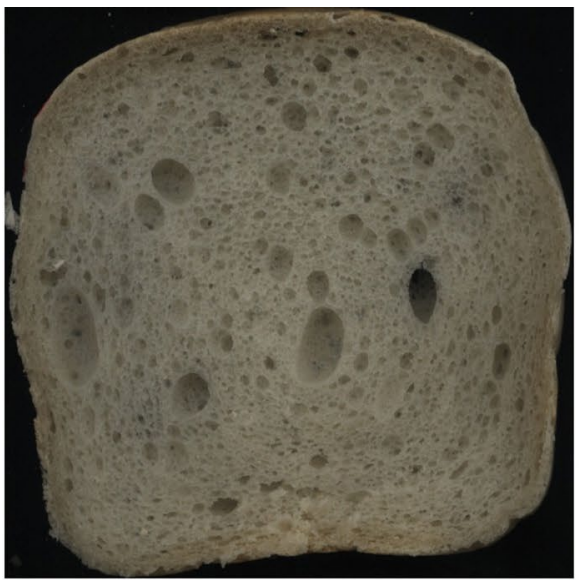

a

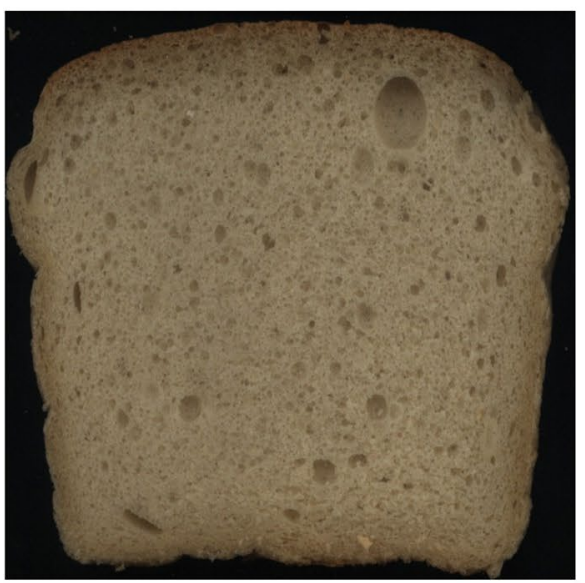

c

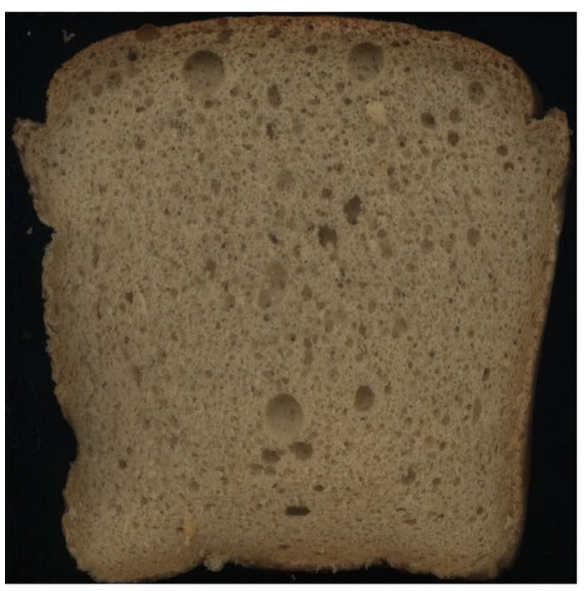

e

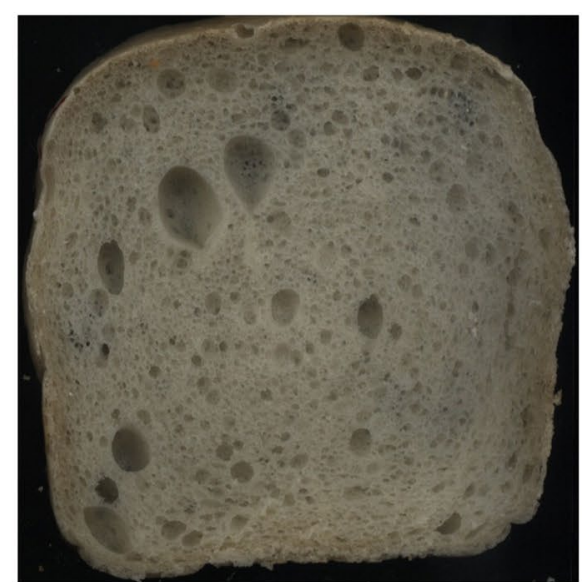

b

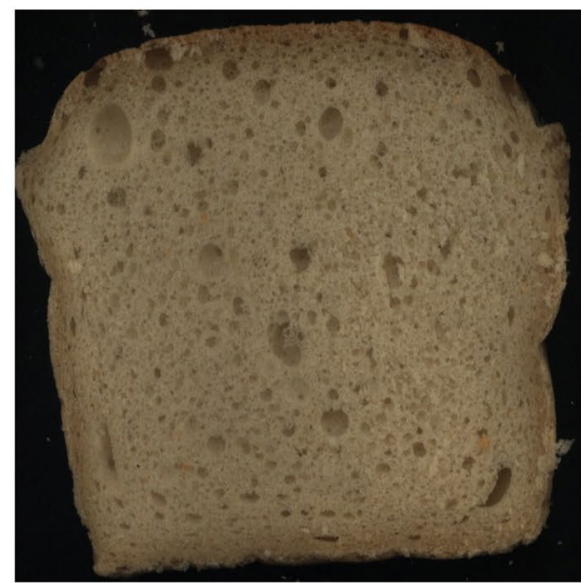

d

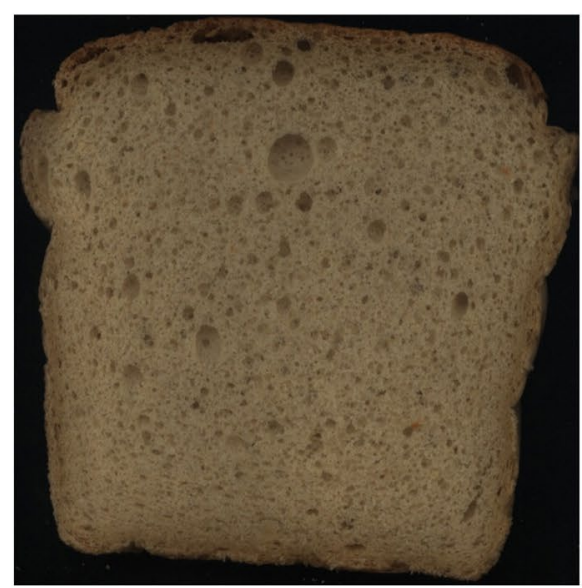

f sample with a simultaneous increase in $a^{*}$ value, which at 12 and $15 \%$ protein concentration was slightly positive indicating a small prevalence of red over green. The increase in rapeseed protein concentration resulted in further increase in $b^{*}$ value corresponding to the proportion of yellow. The $\Delta E$ value (Table 2) calculated on the basis of the obtained data indicates significant differences in the color of bread supplemented with rapeseed protein isolate compared to the control sample. The differences are also noticeable in the crumb photographs shown in Fig. 2. The control sample (Fig. 2a) is characterized by a distinctly lighter color, characteristic for starch-based bread. The presence of rapeseed 
Table 2 Color parameters of gluten-free bread crumb

\begin{tabular}{lllll}
\hline Sample & $L^{*}$ & $a^{*}$ & $b^{*}$ & $\Delta E$ \\
\hline Control GFB & $75.9 \pm 0.36^{\mathrm{d}}$ & $-1.9 \pm 0.07^{\mathrm{a}}$ & $13.1 \pm 0.24^{\mathrm{a}}$ & - \\
$6 \%$ RP & $77.0 \pm 0.17^{\mathrm{e}}$ & $-0.8 \pm 0.05^{\mathrm{b}}$ & $23.9 \pm 0.19^{\mathrm{b}}$ & $10.9 \pm 0.31$ \\
$9 \% \mathrm{RP}$ & $75.0 \pm 0.20^{\mathrm{c}}$ & $-0.2 \pm 0.06^{\mathrm{c}}$ & $26.5 \pm 0.47^{\mathrm{c}}$ & $13.5 \pm 0.53$ \\
$12 \%$ RP & $74.2 \pm 0.48^{\mathrm{b}}$ & $0.1 \pm 0.09^{\mathrm{d}}$ & $28.4 \pm 0.33^{\mathrm{d}}$ & $15.6 \pm 0.41$ \\
$15 \%$ RP & $72.0 \pm 0.44^{\mathrm{a}}$ & $0.9 \pm 0.10^{\mathrm{e}}$ & $29.4 \pm 0.15^{\mathrm{e}}$ & $17.0 \pm 0.31$ \\
One-way ANOVA—p & $<0.01$ & $<0.01$ & $<0.01$ & \\
\hline
\end{tabular}

Mean value of five replication \pm standard deviation

Mean values signed this same letters in particular columns are non-significant different at 0.05 level of confidence protein clearly changes the character of the color to a slightly darker one with a yellow saturation, which is characteristic for traditional bread. This is due to the introduction of amino acids involved in the creation of Maillard reaction products responsible for the color during baking. To sum up, it can be concluded that the introduction of rapeseed protein into the recipe had a positive effect on the changes in the color of the crumb. A decrease in $L^{*}$ value and simultaneous increase in $b^{*}$ value was earlier observed by da Rosa Machado and Thys [9] who were applying 10 or $20 \%$ of cricket powder, as gluten-free bread component and Korus et al. [10] who enriched gluten-free bread with hemp protein, replacing the base starches in quantities of 10 and $20 \%$. In addition, Pico et al. [11] and Coşkun et al. [12] found a darker color of gluten-free bread enriched with protein preparations of various origin. The darker color of gluten-free bread due to the replacement of the mixture of rice flour and corn starch with 5-20\% sunflower protein concentrate was observed by Zorzi et al. [20].

\section{Sensory acceptance of the bread}

From the consumer's point of view, sensory properties are the most important factor having a significant impact on the quality of the finished product. The influence of the use of rapeseed protein isolate in the recipe on the sensory acceptance of gluten-free bread is shown in Fig. 3. The results obtained during the analysis clearly indicate a significant influence of the applied ingredient on the sensory characteristics of the bread. In the case of appearance, an increase in its acceptability was noted in relation to the control bread. However, the highest acceptability was found for bread with the lowest $6 \%$ addition of rapeseed protein, and the increase in its level caused a decrease in the acceptability of the appearance of the bread. Nevertheless, the bread with the highest protein content was still more acceptable than the control sample. Similarly, the structure and porosity were more acceptable when the share of rapeseed protein in the bread recipe was 6 and $9 \%$, while at 12 and $15 \%$ level of this component the acceptability of the structure and porosity

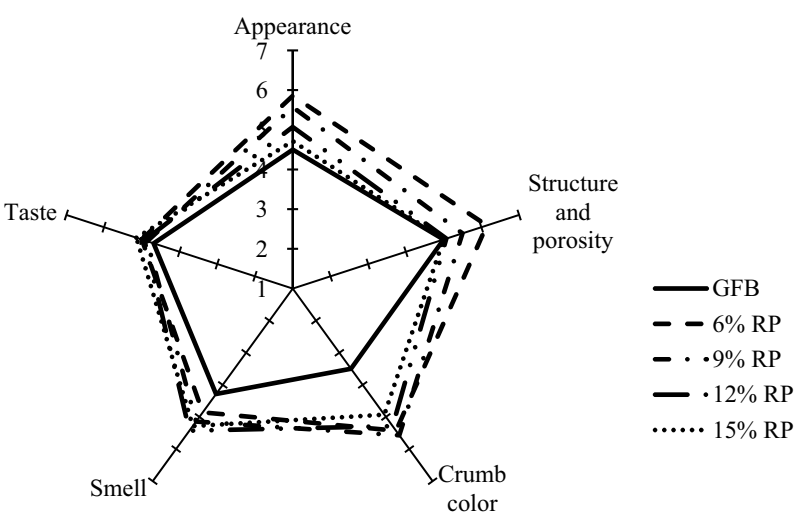

Fig. 3 Results of sensory acceptance of control gluten-free bread and samples enriched with rapeseed protein

was reduced in comparison to the control sample. The presence of rapeseed protein in the bread recipe significantly increased the acceptability of crumb color. While the lowest $6 \%$ addition of protein significantly increased the acceptability of color, further increase in its content had no significant effect. The increase in acceptability of the crumb color is associated with a slightly darker color and a significant increase in $b^{*}$ value indicating increasing proportion of yellow. Improvement of gluten-free bread color after its supplementation with proteins of various origin in quantities between 2 and $10 \%$ was earlier observed by Ziobro et al. [8], Korus et al. [10] and Witczak et al. [25]. A linear correlation $(r=0.84)$ was observed between the sensory acceptability of the color and the values of $b^{*}$. The results of the evaluation of smell acceptability (Fig. 3) indicate a significantly higher evaluation for breads with rapeseed protein compared to the control sample. However, the level of protein addition alone was not significant. The increase in smell acceptability results from the introduction of protein into the recipe, which together with carbohydrates during baking creates an aroma characteristic of traditional bread. The introduction of rapeseed protein into the recipe clearly enriched the aroma of the bread, which, for a control sample, is based mainly on volatile compounds released by cooked starch, and thus 
poor in molecules typical for freshly baked bread, formed at elevated temperatures from non-starch flour components. The results of taste acceptability (Fig. 3) indicate an increase in its value regardless of the level of rapeseed protein.

The positive effect of the addition of protein preparations on the acceptability of gluten-free bread is related to the improvement of its sensory characteristics. An increase in bread volume is usually related to the improvement of structure and porosity of the crumb [26], which enhances its acceptability. Many researchers also point to the darkening of the color and an increase in the proportion of yellow under the influence of protein preparations. These changes make such bread resemble traditional gluten products, which results in an increase in its acceptability [17, 30, 31]. An important factor that could ameliorate sensory acceptability of bread enriched with protein preparations is also the improvement of its smell resulting from the presence of proteins, which contribute to the creation of the characteristic aroma of the bread during baking. Another factor positively influencing the acceptability of bread enriched with protein preparations may be the reduction of crumb hardness and improvement of its elasticity.

\section{Crumb texture}

The analysis of the variability of texture parameters over time allows to assess the storage stability of the bread and the influence of the ingredients or additives on its characteristics. During the storage of bread, there occur a number of changes in the structure of the bread, which are mainly related to the migration of water to the crust and hardening of the crumb, resulting from the retrogradation of starch polymers. All these changes lead to a decrease in product acceptability. To limit these unfavorable phenomena, various types of additives or components are used, whose task is to limit the retrogradation of starch, modify the structure of starch polymers, and control water retention [32]. One of the methods of monitoring structural changes in the crumb is to measure the texture parameters that change over time. These parameters for control bread and samples with rapeseed protein isolate in the recipe are listed in Table 3.

On the first day, the crumb of the control bread had a hardness of $1.29 \mathrm{~N}$. During storage, the hardness of the control bread crumb increased significantly $(p<0.01)$ to over $7 \mathrm{~N}$ on the third day of storage (Table 3), which indicates progressive staling. On the other hand, samples containing rapeseed protein were characterized by higher hardness values compared to the control sample. Nevertheless, the level of the additive itself had no significant effect on the crumb hardness. Higher hardness of the crumb of bread with rapeseed protein on the first day was related to the changes in crumb structure caused by the presence of protein. Since the water content of the rapeseed protein was similar to that of starch, the recipe did not require a variable amount of
Table 3 Texture parameters of gluten-free bread crumb

\begin{tabular}{|c|c|c|c|c|c|}
\hline Sample & Day & Hardness $(\mathrm{N})$ & Springiness (-) & Cohesiveness (-) & Chewiness $(\mathrm{N})$ \\
\hline \multirow[t]{3}{*}{ Control GFB } & 1 & $1.29 \pm 0.18^{\mathrm{a}}$ & $1.00 \pm 0.00^{\mathrm{h}}$ & $0.89 \pm 0.01^{\mathrm{d}}$ & $1.14 \pm 0.15^{\mathrm{a}}$ \\
\hline & 2 & $5.39 \pm 0.29^{\mathrm{ef}}$ & $0.99 \pm 0.01^{\mathrm{gh}}$ & $0.59 \pm 0.06^{\mathrm{b}}$ & $3.15 \pm 0.29^{\mathrm{ef}}$ \\
\hline & 3 & $7.04 \pm 1.13^{\mathrm{g}}$ & $0.96 \pm 0.00^{\mathrm{ef}}$ & $0.53 \pm 0.05^{\mathrm{ab}}$ & $3.59 \pm 0.44^{\mathrm{f}}$ \\
\hline \multirow[t]{3}{*}{$6 \% \mathrm{RP}$} & 1 & $1.88 \pm 0.28^{\mathrm{b}}$ & $0.98 \pm 0.02^{\text {fgh }}$ & $0.86 \pm 0.01^{\mathrm{c}}$ & $1.58 \pm 0.21^{\mathrm{b}}$ \\
\hline & 2 & $5.24 \pm 0.51^{\mathrm{def}}$ & $0.94 \pm 0.01^{\mathrm{cd}}$ & $0.58 \pm 0.04^{\mathrm{ab}}$ & $2.88 \pm 0.43^{\mathrm{def}}$ \\
\hline & 3 & $6.90 \pm 0.80^{\mathrm{g}}$ & $0.94 \pm 0.01^{\mathrm{bcd}}$ & $0.51 \pm 0.06^{\mathrm{ab}}$ & $3.35 \pm 0.74^{\mathrm{ef}}$ \\
\hline \multirow[t]{3}{*}{$9 \% \mathrm{RP}$} & 1 & $1.85 \pm 0.09^{\mathrm{b}}$ & $0.99 \pm 0.02^{\mathrm{gh}}$ & $0.85 \pm 0.01^{\mathrm{c}}$ & $1.55 \pm 0.09^{\mathrm{b}}$ \\
\hline & 2 & $5.81 \pm 0.42^{\mathrm{fg}}$ & $0.94 \pm 0.00^{\mathrm{cd}}$ & $0.54 \pm 0.06^{\mathrm{ab}}$ & $2.96 \pm 0.45^{\mathrm{def}}$ \\
\hline & 3 & $6.74 \pm 0.62^{\mathrm{g}}$ & $0.93 \pm 0.01^{\mathrm{abc}}$ & $0.50 \pm 0.04^{\mathrm{a}}$ & $3.13 \pm 0.51^{\mathrm{ef}}$ \\
\hline \multirow[t]{3}{*}{$12 \% \mathrm{RP}$} & 1 & $1.61 \pm 0.08^{\mathrm{b}}$ & $0.99 \pm 0.01^{\mathrm{gh}}$ & $0.85 \pm 0.01^{\mathrm{c}}$ & $1.34 \pm 0.07^{\mathrm{ab}}$ \\
\hline & 2 & $4.40 \pm 0.69^{\mathrm{cd}}$ & $0.95 \pm 0.01^{\mathrm{de}}$ & $0.55 \pm 0.04^{\mathrm{ab}}$ & $2.29 \pm 0.49^{\mathrm{cd}}$ \\
\hline & 3 & $4.66 \pm 0.42^{\text {cde }}$ & $0.92 \pm 0.01^{\mathrm{a}}$ & $0.48 \pm 0.05^{\mathrm{a}}$ & $2.09 \pm 0.43^{c}$ \\
\hline \multirow[t]{3}{*}{$15 \% \mathrm{RP}$} & 1 & $1.66 \pm 0.20^{\mathrm{b}}$ & $0.97 \pm 0.00^{\mathrm{fg}}$ & $0.83 \pm 0.01^{\mathrm{c}}$ & $1.35 \pm 0.18^{\mathrm{ab}}$ \\
\hline & 2 & $3.98 \pm 0.44^{\mathrm{c}}$ & $0.95 \pm 0.01^{\mathrm{de}}$ & $0.59 \pm 0.05^{\mathrm{b}}$ & $2.25 \pm 0.43^{\mathrm{cd}}$ \\
\hline & 3 & $5.38 \pm 0.64^{\mathrm{ef}}$ & $0.93 \pm 0.00^{\mathrm{ab}}$ & $0.52 \pm 0.00^{\mathrm{ab}}$ & $2.60 \pm 0.66^{\mathrm{cde}}$ \\
\hline \multicolumn{6}{|l|}{ Two-way ANOVA $-p$} \\
\hline Factor A (level of protein) & & $<0.01$ & $<0.01$ & $<0.01$ & $<0.01$ \\
\hline Factor B (time) & & $<0.01$ & $<0.01$ & $<0.01$ & $<0.01$ \\
\hline Factor $\mathrm{A} \times$ Factor $\mathrm{B}$ & & $<0.01$ & $<0.01$ & $<0.01$ & $<0.01$ \\
\hline
\end{tabular}

Mean value of three replication \pm standard deviation

Mean values signed this same letters in particular columns are non-significant different at 0.05 level of confidence 
water. Therefore, the higher hardness of the crumb observed for bread with rapeseed protein on the first day was due to protein-starch interactions rather than insufficient protein hydration. The addition of protein decreased porosity and the presence of large pores, causing an increase in pores density (Table 1), and the resulting more compact structure of bread crumb could contribute to a slight increase in its hardness. The available literature data indicate a varying influence of protein preparations on crumb hardness. Ziobro et al. [8] reported that the replacement of $10 \%$ of base starches with peas, lupine and albumin proteins reduce the hardness of the crumb, while collagen increases its value. On the other hand, Berta et al. [30], replacing starch with corn zeins in the recipe, observed a decrease in bread hardness and an increase in springiness. In addition, Kowalczewski et al. [31] found a decrease of hardness and chewiness of bread enriched with $2-10 \%$ high-protein cricket flour. The decrease in crumb hardness of gluten-free bread as a result of the addition of 5-20\% sunflower protein concentrate was also observed by Zorzi et al. [20]. On the other hand, da Rosa Machado and Thys [9], Coşkun et al. [12], Ziobro et al. [17], Witczak et al. [25] and Han et al. [27] observed an increase in crumb hardness resulting from the presence of various protein preparations in the recipe.

During storage, the hardness of all bread samples increased to varying degrees. The addition of rapeseed protein at the level of 6 and $9 \%$ had no significant effect on changes in hardness, the values of which did not differ from those of the control sample. On the other hand, bread crumb with 12 and $15 \%$ of protein on the second and third day was characterized by significantly lower hardness compared to the control sample. This phenomenon could be caused by several factors. Partial replacement of the starch with protein modifies the structure of the crumb due to the stabilizing effect of amphiphilic protein chains on the fermentation gases and causes a decrease in the concentration of starch polymers that tend to retrograde. Moreover, the presence of denatured protein in the baking process strengthens the structure of the crumb, limiting starch retrogradation. The two-factor analysis of variance confirmed that both the level of rapeseed protein and storage time significantly $(p<0.01)$ affected the crumb hardness. Moreover, a negative linear correlation between hardness and porosity was observed $(r=-0.74)$.

The share of rapeseed protein in the recipe and storage time had a significant impact $(p<0.01)$ on the springiness of the bread crumb under analysis. On the first day, the crumb of breads with rapeseed protein was characterized by a similar springiness as the control sample (Table 3), only the breads with the highest proportion of rapeseed protein were characterized by significantly lower elasticity than the control sample. The springiness decreased during storage, and the lowest values of this parameter were recorded on the third day. Breads containing rapeseed protein were characterized by lower values of springiness during storage, with the level of protein addition also having a significant $(p<0.01)$ effect. The structure of the crumb had a significant impact on its elasticity. Positive linear correlations between crumb elasticity on one hand and its porosity $(r=0.88)$ and number of pores $>5 \mathrm{~mm}(r=0.93)$ on the other, were observed here. The elasticity of the crumb negatively correlated with the density of pores $(r=-0.93)$.

The values of crumb cohesiveness are presented in Table 3. They generally decreased with time, although on the second and third days of storage, the cohesiveness of the control sample and breads with rapeseed protein were at a similar level. Since the crumb structure has a significant influence on the crumb cohesiveness, a positive linear correlation between the crumb cohesiveness and its porosity $(r=0.91)$ and the number of pores $>5 \mathrm{~mm}(r=0.86)$ were observed here. The cohesiveness of the crumb negatively correlated with the pore density $(r=-0.86)$.

The chewiness is closely correlated $(r=0.99)$ with the hardness, the results of which have a decisive influence on the values of this parameter, so the effect of using rapeseed protein in the recipe was similar here. The smallest chewiness on the first day was found for control bread (Table 3). Slightly higher values of this parameter were found for breads with a share of rapeseed protein, although the level of addition was less important. As in the case of hardness, chewiness increased during storage, however, the addition of protein at 6 or $9 \%$ did not significantly affect the values of this parameter on particular days. It was only the higher proportion of protein, at the level of 12 or $15 \%$, that had a significant effect on the decrease in the chewiness values on particular days in comparison with the control sample. As in the case of hardness, this is related to the introduction of a protein characterized by surface activity, strengthening of the crumb structure through denatured protein and a reduction of the amount of starch polymers capable to retrograde.

\section{Thermal properties}

Retrogradation of branched amylopectin chains, which associate during storage, results in crumb hardening and water migration from crumb to crust, and therefore, should be regarded as one of the major factors of staling. The thermograms of gluten-free bread showed the presence of an endothermic peak associated with the decomposition of recrystallized amylopectin. The temperature at the beginning of this transformation ranged from about 51 to $59^{\circ} \mathrm{C}$, with the control bread crumb having the lowest values. The presence of rapeseed protein caused an increase of onset temperature, but no significant trends and differences between varying addition levels could be observed. Peak transition temperature occurred in the range between 64 and $70{ }^{\circ} \mathrm{C}$, 
while the end of the transition could be observed between 76 and $80{ }^{\circ} \mathrm{C}$ (data not shown). The two-factor analysis of variance did not show any significant influence of the level of protein addition and storage time on the values of the discussed parameters, and these observations confirm previous information available in the literature [10, 32, 33].

On the other hand, the enthalpy values of the transition were significantly $(p<0.01)$ affected by both the share of rapeseed protein in the recipe and the storage time of the bread. On the day of baking, the crumb of control bread was characterized by the lowest value of the enthalpy of amylopectin breakdown (Fig. 4). As in the case of crumb hardness (Table 3), samples with rapeseed protein were characterized by higher enthalpy values of the decomposition of recrystallized amylopectin. On the second day of the analysis, enthalpy values for samples with 6 and $9 \%$ addition of rapeseed protein were similar to those found for the control sample. On the other hand, a larger addition of 12 or $15 \%$ of protein caused a significant increase in its value. On the third day of storage, the decomposition enthalpy values of the recrystallized amylopectin in all samples were at similar levels and no significant positive or negative effect of rapeseed protein on this parameter was found. These data do not follow the results obtained for changes in crumb hardness during storage, because breads with 12 or $15 \%$ rapeseed protein were characterized by significantly lower hardness on the last day of storage compared to the control sample, indicating a slower aging process. The discrepancy may be due to the fact that amylopectin retrogradation is only one of the factors responsible for bread staling process, which in the case of traditional bread was shown to be much more complex and controlled by starch-protein interactions. Hence, the measurement of crumb hardness is more representative of the aging of the bread crumb. The variable influence of protein preparations on the enthalpy values of the recreated

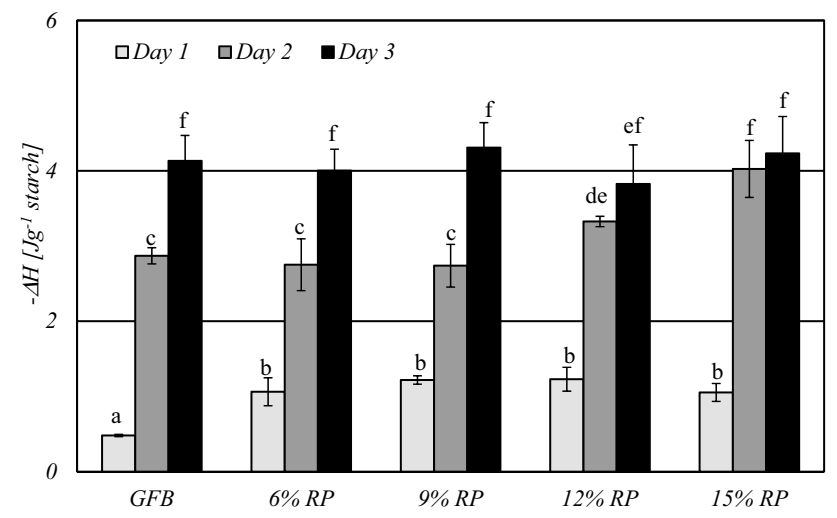

Fig. 4 Effect of storage time on enthalpy of amylopectin melting after retrogradation of control gluten-free bread (GFB) and samples enriched with rapeseed protein (RP). Mean values signed this same letters are non-significant different at 0.05 level of confidence amylopectin distribution is indicated by available literature data. Korus et al. [10] found a significant decrease in amylopectin decomposition enthalpy caused by the presence of 10 or $20 \%$ hemp proteins. In addition, Ziobro et al. [8] observed a similar decrease after the addition of pea or lupin proteins or collagen preparation. Phongthai et al. [26] indicate that $2 \%$ rice proteins and albumin diminish bread staling. A reduction in the aging trend of bread enriched with yoghurt was also observed by Graça et al. [28]. On the other hand, Witczak et al. [25] did not observe any significant effect of potato protein concentrate, in the amount between 2 and $10 \%$, on the enthalpy values of the retrograded amylopectin breakdown. Although amylopectin retrogradation is only one of the factors influencing the aging of bread, i.e., the increase in crumb hardness over time, a positive linear correlation was found between crumb hardness and the enthalpy of the recrystallized amylopectin decomposition $(r=0.89)$. Moreover, the values of the recrystallized amylopectin decomposition enthalpy correlated significantly with springiness $(r=-0.70)$, cohesiveness $(r=0.84)$ and chewiness $(r=-0.85)$.

\section{Conclusion}

On the basis of the obtained results, it was found that the presence of protein in concentrations of 12 and $15 \%$ caused a significant increase in bread volume. A significant decrease in porosity, an increase in pore density and a decrease in the percentage of large pores $>5 \mathrm{~mm}$ of bread crumb with rapeseed protein were also found in comparison to the control sample. Changes in the characteristics of the crumb were also confirmed by photographs of its structure. The calculated value of $\Delta E$ indicates significant differences in the color of bread supplemented with rapeseed protein isolate compared to the control sample, which is mainly related to the increase in $b^{*}$ value corresponding to the share of yellow. Sensory evaluation showed an increase in acceptability of particular traits under the influence of rapeseed protein addition. Bread crumb with 12 and $15 \%$ protein addition on the second and third days of storage was characterized by significantly lower hardness compared to the control sample, indicating a retardation of the aging process. Partial replacement of starch with protein caused structure modification of the crumb due to gas stabilization effects and a decrease in concentration of starch polymers prone to retrogradation. However, the reduction of long-term amylopectin retrogradation by rapeseed protein was not confirmed. In conclusion, it should be pointed out that rapeseed protein can be a valuable component of gluten-free bread. Its introduction to the recipe in addition to nutritional enrichment has resulted in a significant improvement in bread characteristics, including an increase in the volume of loaves, improvement in 
crumb structure and sensory characteristics of the bread and a reduction in crumb hardening during storage.

Acknowledgements The authors thank NapiFeryn BioTech Sp. z o.o., Poland for donating rapeseed protein.

Funding The work was financed by a subsidy of the Ministry of Science and Higher Education for the University of Agriculture in Krakow for 2020.

Data availability All data concerning the presented studies are included in the paper.

\section{Declarations}

Conflict of interest The authors declare that they have no conflict of interest.

Ethical standards This article does not contain any studies with human participants or animals performed by any of the authors.

Open Access This article is licensed under a Creative Commons Attribution 4.0 International License, which permits use, sharing, adaptation, distribution and reproduction in any medium or format, as long as you give appropriate credit to the original author(s) and the source, provide a link to the Creative Commons licence, and indicate if changes were made. The images or other third party material in this article are included in the article's Creative Commons licence, unless indicated otherwise in a credit line to the material. If material is not included in the article's Creative Commons licence and your intended use is not permitted by statutory regulation or exceeds the permitted use, you will need to obtain permission directly from the copyright holder. To view a copy of this licence, visit http://creativecommons.org/licenses/by/4.0/.

\section{References}

1. Alvarez-Jubete L, Auty M, Arendt EK, Gallagher E (2010) Baking properties and microstructure of pseudocereal flours in gluten-free bread formulations. Eur Food Res Technol 230:437. https://doi. org/10.1007/s00217-009-1184-z

2. Roman L, Belorio M, Gómez M (2019) Gluten-free breads: the gap between research and commercial reality. Compr Rev Food Sci Food Saf 18:690-702. https://doi.org/10.1111/1541-4337. 12437

3. Witczak M, Ziobro R, Juszczak L, Korus J (2021) Potato flakes (Solanum tuberosum L.) as a factor modifying the rheological properties of dough and limiting the staling of gluten-free bread. Food Bioproc Technol 14:65-77. https://doi.org/10.1007/ s11947-020-02573-z

4. Melini F, Melini V, Luziatelli F, Ruzzi M (2017) Current and forward-looking approaches to technological and nutritional improvements of gluten-free bread with legume flours: a critical review. Compr Rev Food Sci Food Saf 16:1101-1122. https://doi. org/10.1111/1541-4337.12279

5. Segura MEM, Rosell CM (2011) Chemical composition and starch digestibility of different gluten-free breads. Plant Foods Hum Nutr 66:224-230. https://doi.org/10.1007/s11130-011-0244-2

6. Deora NS, Deswal A, Mishra HN (2015) Functionality of alternative protein in gluten-free product development. Food Sci Technol Int 21:364-379. https://doi.org/10.1177/1082013214538984
7. Naqash F, Gani A, Gani A, Masoodi FA (2017) Gluten-free baking: combating the challenges-a review. Trends Food Sci Technol 66:98-107. https://doi.org/10.1016/j.tifs.2017.06.004

8. Ziobro R, Witczak T, Juszczak L, Korus J (2013) Supplementation of gluten-free bread with non-gluten proteins. Effect on dough rheological properties and bread characteristic. Food Hydrocoll 32:213-220. https://doi.org/10.1016/j.foodhyd.2013.01.006

9. da Rosa Machado C, Thys RCS (2019) Cricket powder (Gryllus assimilis) as a new alternative protein source for gluten-free breads. Innov Food Sci Emerg Technol. https://doi.org/10.1016/j. ifset.2019.102180

10. Korus J, Witczak M, Ziobro R, Juszczak L (2017) Hemp (Cannabis sativa subsp. sativa) flour and protein preparation as natural nutrients and structure forming agents in starch based gluten-free bread. LWT-Food Sci Technol 84:143-150. https://doi.org/10. 1016/j.lwt.2017.05.046

11. Pico J, Reguilón MP, Bernal J, Gómez M (2016) Effect of rice, pea, egg white and whey proteins on crust quality of rice flourcorn starch based gluten-free breads. J Cereal Sci 86:92-101. https://doi.org/10.1016/j.jcs.2019.01.014

12. Coşkun Ö, Pehlivanoğlu H, Gülseren İ (2020) Pilot scale assessment for seed protein enrichment of gluten-free breads at varying water content levels and after protein modification treatments. J Food Proc Preserv 44:e14512. https://doi.org/10.1111/jfpp.14512

13. Vijaykrishnaraj M, Roopa BS, Prabhasankar P (2016) Preparation of gluten free bread enriched with green mussel (Perna canalicu$l u s$ ) protein hydrolysates and characterization of peptides responsible for mussel flavor. Food Chem 211:715-725. https://doi.org/ 10.1016/j.foodchem.2016.05.094

14. Marco C, Rosell CM (2008) Functional and rheological properties of protein enriched gluten free composite flours. J Food Eng 88:94-103. https://doi.org/10.1016/j.jfoodeng.2008.01.018

15. Nunes MHB, Ryan LAM, Arendt EK (2009) Effect of low lactose dairy powder addition on the properties of gluten-free batters and bread quality. Eur Food Res Technol 229:31-41. https://doi.org/ 10.1007/s00217-009-1023-2

16. Miñarro B, Normahomed I, Guamis B, Capellas M (2010) Influence of unicellular protein on gluten-free bread characteristics. Eur Food Res Technol 231:171-179. https://doi.org/10.1007/ s00217-010-1269-8

17. Ziobro R, Juszczak L, Witczak M, Korus J (2016) Non-gluten proteins as structure forming agents in gluten free bread. J Food Sci Technol 53(1):571-580. https://doi.org/10.1007/ s13197-015-2043-5

18. Wang K, Lu F, Li Z, Zhao L, Han C (2017) Recent developments in gluten-free bread baking approaches: a review. Food Sci Technol 37:1-9. https://doi.org/10.1590/1678-457X.01417

19. Khoury DE, Balfour-Ducharme S, Joye IJ (2018) A review on the gluten-free diet: technological and nutritional challenges. Nutrients 10:1410. https://doi.org/10.3390/nu10101410

20. Zorzi CZ, Garske RP, Flôres SH, Thys RCS (2020) Sunflower protein concentrate: a possible and beneficial ingredient for glutenfree bread. Innov Food Sci Emerg Technol 66:102539. https://doi. org/10.1016/j.ifset.2020.102539

21. Commission Implementing Decision of 1 July 2014 authorising the placing on the market of rapeseed protein as a novel food ingredient under Regulation (EC) No 258/97 of the European Parliament and of the Council. Off J Eur Union L:196/27

22. Ostrowska A, Kozłowska M, Rachwał D, Wnukowski P, Nebesny E, Rosicka-Kaczmarek J (2018) Rapeseed protein-fibre concentrate: chemical composition and functional properties. Food Sci Technol Qual 25(4):86-99. https://doi.org/10.15193/Zntj/2018/ $117 / 261$

23. Chmielewska A, Kozłowska M, Rachwał D, Wnukowski P, Amarowicz R, Nebesny E, Rosicka-Kaczmarek J (2020) Canola/rapeseed protein-nutritional value, functionality and food 
application: a review. Crit Rev Food Sci Nutr. https://doi.org/10. 1080/10408398.2020.1809342

24. AOAC, Official methods of analysis, Association of Official Analytical Chemists International, Gainthersburg, MD, 2006

25. Witczak T, Juszczak L, Ziobro R, Korus J (2017) Rheology of gluten-free dough and physical characteristics of bread with potato protein. J Food Proc Eng 40:e12491. https://doi.org/10.1111/jfpe. 12491

26. Phongthai S, D'Amico S, Schoenlechner R, Rawdkuen S (2016) Comparative study of rice bran protein concentrate and egg albumin on gluten-free bread properties. J Cereal Sci 72:38-45. https://doi.org/10.1016/j.jcs.2016.09.015

27. Han A, Romero HM, Nishijima N, Ichimura T, Handa A, Xu C, Zhang Y (2019) Effect of egg white solids on the rheological properties and bread making performance of gluten-free batter. Food Hydrocoll 87:287-296. https://doi.org/10.1016/j.foodhyd. 2018.08.022

28. Graça C, Raymundo A, Sousa I (2020) Yogurt as an alternative ingredient to improve the functional and nutritional properties of gluten-free breads. Foods 9:111. https://doi.org/10.3390/foods 9020111

29. Bravo-Núñez A, Sahagún M, Gómez M (2019) Assessing the importance of protein interactions and hydration level on protein-enriched gluten-free breads: a novel approach. Food Bioproc Technol 12:820-828. https://doi.org/10.1007/s11947-019-02258-2
30. Berta M, Koelewijn I, Öhgren C, Stading M (2019) Effect of zein protein and hydroxypropyl methylcellulose on the texture of model gluten-free bread. J Texture Stud 50(4):341-349. https:// doi.org/10.1111/jtxs.12394

31. Kowalczewski PŁ, Walkowiak K, Masewicz Ł, Bartczak O, Lewandowicz J, Kubiak P, Baranowska HM (2019) Gluten-free bread with cricket powder-mechanical properties and molecular water dynamics in dough and ready product. Foods 8:240. https:// doi.org/10.3390/foods 8070240

32. Witczak M, Korus J, Ziobro R, Juszczak L (2019) Waxy starch as dough component and anti-staling agent in gluten-free bread. LWT-Food Sci Technol 99:476-482. https://doi.org/10.1016/j.lwt. 2018.10.009

33. Korus J, Witczak M, Ziobro R, Juszczak L (2015) The influence of acorn flour on rheological properties of gluten-free dough and physical characteristics of the bread. Eur Food Res Technol 240:1135-1143. https://doi.org/10.1007/s00217-015-2417-y

Publisher's Note Springer Nature remains neutral with regard to jurisdictional claims in published maps and institutional affiliations. 